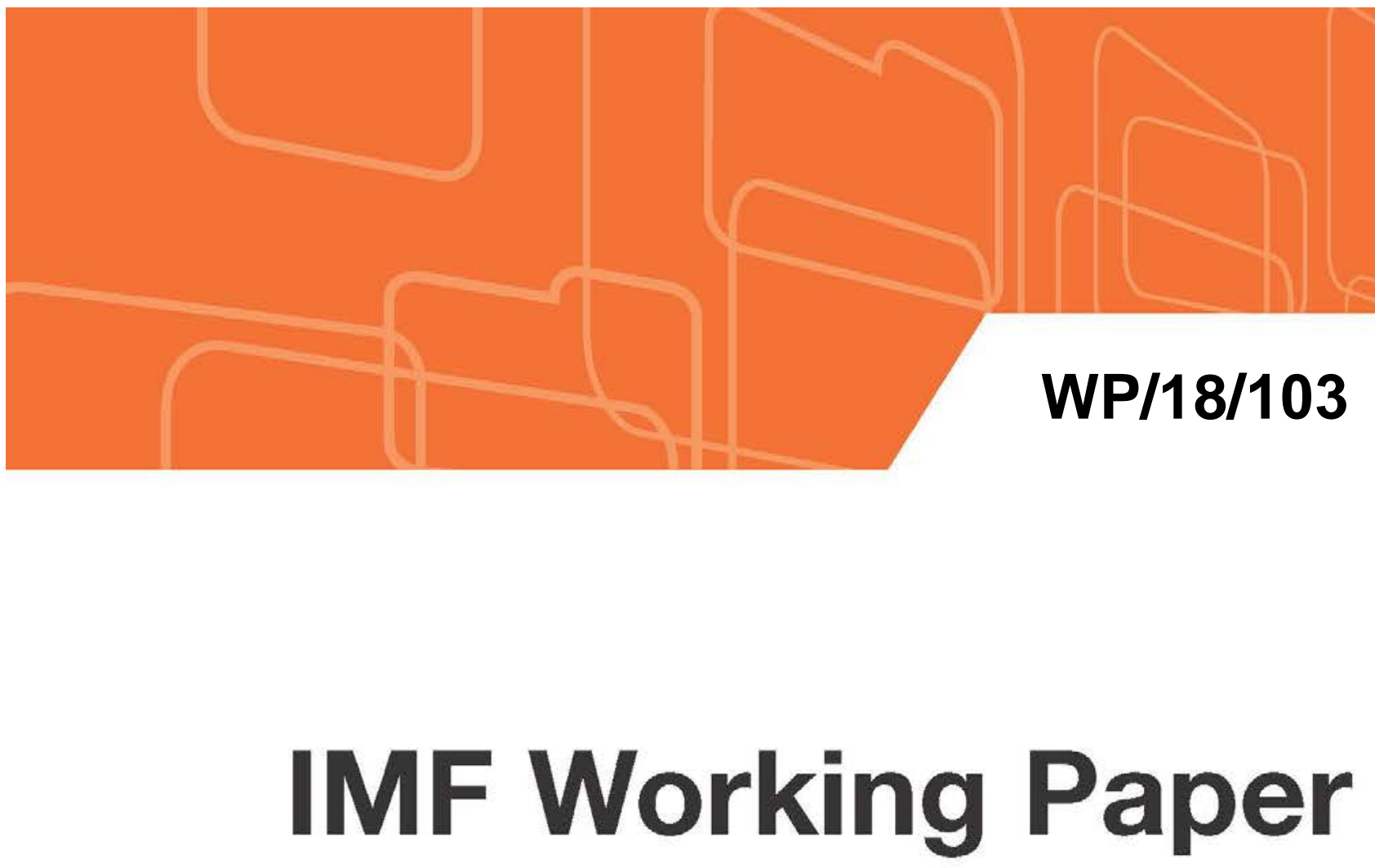

\title{
Cross-Border Transmission of Fiscal Shocks: The Role of Monetary Conditions
}

by Patrick Blagrave, Giang Ho, Ksenia Koloskova, Esteban Vesperoni

IMF Working Papers describe research in progress by the author(s) and are published to elicit comments and to encourage debate. The views expressed in IMF Working Papers are those of the author(s) and do not necessarily represent the views of the IMF, its Executive Board, or IMF management. 


\title{
IMF Working Paper
}

\author{
Research Department
}

\begin{abstract}
Cross-Border Transmission of Fiscal Shocks: The Role of Monetary Conditions
Prepared by Patrick Blagrave, Giang Ho, Ksenia Koloskova, Esteban Vesperoni ${ }^{1}$
\end{abstract}

Authorized for distribution by Helge Berger

May 2018

IMF Working Papers describe research in progress by the author(s) and are published to elicit comments and to encourage debate. The views expressed in IMF Working Papers are those of the author(s) and do not necessarily represent the views of the IMF, its Executive Board, or IMF management.

\begin{abstract}
Fiscal stimulus was widely advocated during the global crisis, a period characterized by monetary policy constrained by the effective lower bound (ELB) in many countries, in part because of expected positive spillovers. Standard New Keynesian models predict the crossborder transmission of fiscal shocks is stronger when monetary policy is constrained in recipients. However, the empirical evidence is scarce. This paper bridges this gap by looking at the impact of fiscal shocks in systemic (source) economies on output and demand components in a large group of (recipient) countries, under different monetary policy conditions. Empirical results are compared to simulations with a state-of-the-art estimated open-economy New Keynesian model. Our results corroborate model predictions, finding larger spillovers when recipients are at the ELB, driven by stronger responses of investment and consumption relative to normal times.
\end{abstract}

JEL Classification Numbers: C33, E52, E62, H20

Keywords: Fiscal policy; monetary policy; effective lower bound; international spillovers Author’s E-Mail Address: pblagrave@imf.org; gho@imf.org; kkoloskova@imf.org; evesperoni@imf.org

\footnotetext{
${ }^{1}$ We thank Sung Eun Jung for excellent research support, Jesper Linde for insightful discussions and sharing model codes, as well as Helge Berger, Gian Maria Milesi-Ferretti and Maurice Obstfeld for insightful comments. This draft has also benefitted from comments received in several seminars at central banks and ministries of finance in the Euro Area, as well as the annual joint ECB-Bank of England-IMF Spillover workshop. The opinions expressed herein are solely the responsibility of the authors and should not be interpreted as reflecting those of the IMF, its Executive Board, or IMG management.
} 


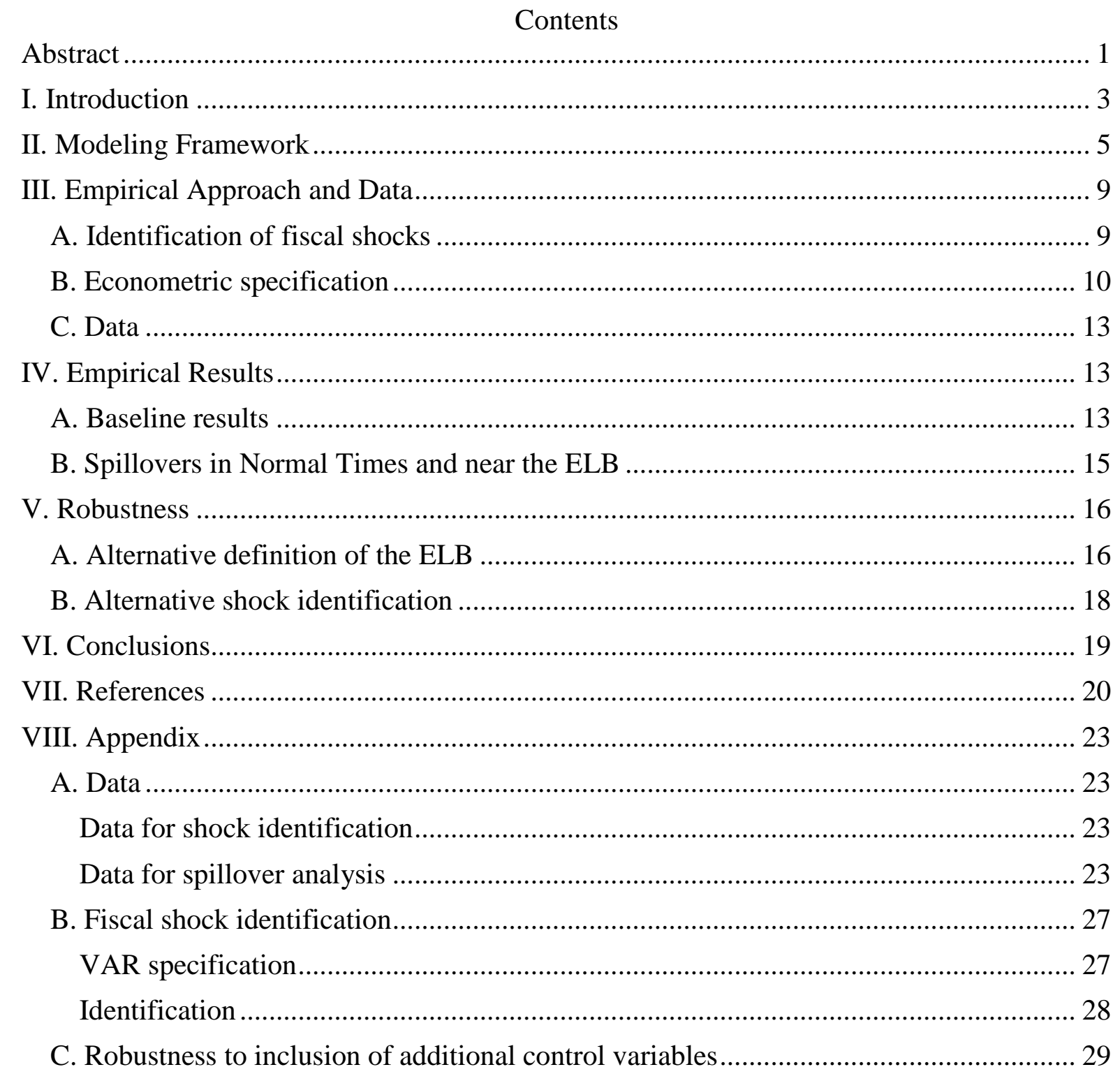




\section{INTRODUCTION}

Fiscal stimulus was widely advocated at the time of the global financial crisis, a period characterized by substantial economic slack and monetary policy constrained by the effective lower bound (ELB) in many countries. With the benefit of hindsight, such stimulus is believed to have had positive cross-border spillovers, which added to its effectiveness at the multinational level (see e.g. Freedman and others 2010). While the implications of the ELB for the effectiveness of fiscal policy domestically have received significant attention in the literature (see Christiano, Eichenbaum and Rebelo 2011, Eggertson 2011, and Woodford 2011, among others), the importance of monetary policy constraints for the transmission of international spillovers has been explored much less.

Model-based analysis suggests that spillovers from fiscal policy can be larger when monetary policy is accommodative, such as when constrained by the effective lower bound - in this situation a decline in real interest rates amplifies the response of domestic demand components to foreign demand shocks (Blanchard, Erceg, and Linde 2016, Erceg and Linde 2013, Freedman et al. 2010, In’t Veld 2017). However, empirical literature on cross-border spillovers from fiscal shocks - and how these are transmitted-is less conclusive. Several methods for identification of fiscal shocks and a variety of econometric techniques have been used to study the overall size of spillovers from fiscal policy (Auerbach and Gorodnichenko 2013, Beetsma et. al 2006, Beetsma and Giuliodori 2011, Corsetti and Mueller 2013, Goujard 2017, Nicar 2015). These studies typically find that GDP spillovers from fiscal shocks in major economies are sizeable. However, much less is understood about the transmission of such shocks - that is, which components of recipient-country output respond more to external fiscal shocks_-and how these responses are affected by different economic and policy conditions.

We bridge the gap between the model-based and empirical literature on fiscal spillovers by estimating the response of economic activity to an external fiscal shock in normal times and when monetary policy in the recipient country is near the ELB, looking not only at the response of GDP but also at that of its demand components. These results are compared to those of an estimated two-country New Keynesian model-specifically, a flexible-exchangerate version of the model of Blanchard, Erceg and Linde (2016). The model predicts that trade is the main channel of transmission in normal times, with spillovers operating through higher exports. However, when the recipient economy is at the ELB, spillovers are larger and are propagated through lower real interest rates in the recipient, which leads to somewhat stronger consumption and much stronger investment. Our empirical analysis corroborates these model-based predictions.

More specifically, we estimate spillovers from tax and spending shocks in five major economies - France, Germany, Japan, United Kingdom, and United States - onto a sample of 55 advanced and emerging economies in normal times and when interest rates in recipient countries were close to zero. Our main findings are: (i) fiscal spillovers are larger when 
monetary policy is accommodative in recipient economies; (ii) the response of various output components shows that these larger spillovers are driven by stronger responses of investment and consumption relative to normal times, confirming the transmission mechanisms in a standard New Keynesian two-country model; and (iii) the fiscal instrument matters, as spillovers from spending shocks are larger than those from tax shocks, which is in line with the size of respective domestic multipliers generally found in the literature. Our findings are derived for a wider variety of fiscal shocks_-both spending and tax shocks covering both expansions and consolidations - and a broader sample of recipient countries than in previous studies in the literature.

Evidence in support of non-linearities in transmission of fiscal spillovers is mixed in the literature. Faccini et. al (2016) and Hebous and Zimmerman (2013) study fiscal spillovers in times of recessions/crises, but spillover estimates are no different than in normal times. Auerbach and Gorodnichenko (2013) also study spillovers in recessions and booms, and find that spillovers can be larger when the recipient country is in a recession. An earlier version of their paper examines output components, finding that the point-estimate response of all components is higher in recessions, although the results are in most cases not statistically significant, especially when considering the entire sample. Papers looking at transmission of fiscal spillovers - though not differentiating based on economic conditions-include Faccini et al (2016) and Corsetti and Mueller (2013). These find that the response of a recipient's net exports to a foreign fiscal expansion is typically not statistically significant, or is negative, while consumption and investment rise in response to this shock driven by a fall in the real interest rate. Corsetti, Meier, and Mueller (2012) show that these results are consistent with a model with government spending reversals. Hebous and Zimmerman (2013), on the contrary, find that spillovers from foreign fiscal shocks are mainly transmitted through higher exports, while the evidence for the interest rate response is limited. ${ }^{2}$

Our paper offers several innovations relative to existing literature. First, we focus on spillovers under different monetary policy conditions, which, as we show using a structural model, matters significantly for the transmission and size of the output response. Second, we use a much larger sample of recipient economies compared to what has been studied in the literature, covering 85 percent of the world GDP - this includes not only advanced economies, but also many emerging markets. Finally, while the literature has tended to focus only on shocks to government spending, ${ }^{3}$ we look at shocks to both spending and to tax revenues, which allows us to estimate how spillovers vary with the fiscal policy instrument.

This paper is structured as follows: Section 2 presents model simulations to highlight the operation of the main transmission channels. Section 3 documents our empirical method,

\footnotetext{
${ }^{2}$ A number of studies examine fiscal spillovers within the euro area, including Elekdag and Muir (2014).

${ }^{3}$ Hebous and Zimmerman (2013) include both changes in spending and taxes, however their fiscal shocks include only consolidation episodes.
} 
including identification of fiscal shocks and estimation of spillovers. Section 4 presents our main empirical results. Robustness checks are provided in Section 5. Sections 6 concludes.

\section{MOdeling FrameWORK}

The cross-border impact of fiscal policy depends on the initial domestic effects in the country changing its fiscal stance and factors influencing their transmission abroad. In standard openeconomy macroeconomic models, a fiscal shock is transmitted abroad primarily through the trade channel, consisting of: (i) expenditure shifting, which is the direct impact of fiscal policy on the demand for partner-country exports through higher domestic demand, and (ii) expenditure switching, which captures spillovers from substitution between domestic- and foreign-goods consumption triggered by changes in the real exchange rate. In addition to the trade channel, the response of financial variables — such as global interest rates and the slope of the yield curve - can trigger spillovers through changes in global financial conditions. Overall, the relative strength of each transmission channel will depend on the extent of trade and financial linkages between the source and the recipient countries.

Standard models suggest monetary policy accommodation of the fiscal shock can amplify spillovers. Under normal circumstances, monetary policy reacts to counter the demand effects of a fiscal expansion in the source country. Similarly, when faced with an increase in foreign demand, a recipient country would tighten monetary policy to curb inflation. However, if nominal interest rates in the recipient country do not rise in response to higher expected inflation following a positive external shock—as could be the case if monetary policy is operating at the effective lower bound —real interest rates decline, crowding in domestic demand. Low interest rates also prevent the central bank from counteracting a negative shock by reducing rates further.

To illustrate how the cross-border transmission of fiscal shocks differs depending on the response of monetary policy in recipient countries, we conduct simulations using a variant of the two-country DSGE model of Blanchard, Erceg and Linde (2016). ${ }^{4}$ Relative to that model, the only adaptation is that both countries have flexible exchange rates, and thus the ability to pursue independent monetary policy. Below, we provide a cursory overview of their modeladditional information on model structure, and parameter estimation, is available in the original paper.

The model comprises two countries, which we refer to as "source" and "recipient"-the structure of the two countries is identical, but the source is twice as large as the recipient. Each country consumes consumption and investment goods, consisting of both domestically produced and imported content. The mix of imported and domestically produced goods in both consumption and investment reflects preferences of domestic agents-which reflect home bias-and the share of imports is costly to adjust. There are two types of households:

\footnotetext{
${ }^{4}$ This model was chosen because it captures well the transmission channels outlined above.
} 
those who are forward looking and make intertemporal consumption, labor-supply, and capital-accumulation decisions; and those who simply consume their after-tax disposable income ("hand-to-mouth" households). The former group earns labor income and leases capital — both of which are taxed — and receives a share of the profits of all firms, as well as a lump-sum government transfer (which can be negative if it takes the form of a tax). In making their utility-maximization decision, households take as given prices, taxes and transfers, and aggregate quantities such as lagged consumption, and preferences can exhibit external habit formation, implying consumption adjusts gradually (as in Smets and Wouters 2003, 2007). The model also assumes that investment is costly to adjust, as in Christiano, Eichenbaum, and Evans (2005).

Monetary policy is set according to a Taylor rule, where interest rates respond to deviations of inflation from target and the output gap. There is also a term that slows the adjustment of rates over time-adding inertia — and nominal interest rates are subject to a zero-bound constraint. The government in the model can levy taxes to finance government purchasesthe latter have no direct effect on the utility of households or the private sector's production function. The budget does not need to be balanced in any given period-the government can issue debt, but must satisfy its intertemporal budget constraint. It is assumed that labor taxes are adjusted to stabilize the deficit and debt/GDP ratio. Exogenous components of spending and taxes follow autoregressive processes with the persistence parameter equal to 0.9 .

We use the model to estimate the impact on the recipient country's output of a temporary increase in government spending or a decrease in labor tax revenues in the source countryequivalent to one percent of GDP of the latter. We also consider an overall fiscal shock-an increase in the public deficit of one percent of GDP stemming in equal parts from a temporary increase in government spending and a reduction in labor taxes. The fiscal shock happens in the first quarter and causes a persistent increase in spending and taxes. Spillovers from each of these fiscal shocks are considered both when interest rates in the recipient country respond normally and when the response is constrained by the effective lower bound. ${ }^{5}$ Figure 1 shows that spending shocks have larger spillover effects than tax shocks, and that all shocks have considerably larger effects when monetary policy is constrained in the recipient country.

\footnotetext{
${ }^{5}$ This constraint is endogenously generated in the model through a combination of negative consumption and productivity shocks. The decline in output at the peak is about 20 percent relative to the steady state and the ELB lasts for 13 quarters. We simulate the impact of very small fiscal shocks, which do not change the ELB duration. We then linearly rescale the impulse responses to correspond to a 1 percent of GDP shock for ease of interpretation.
} 


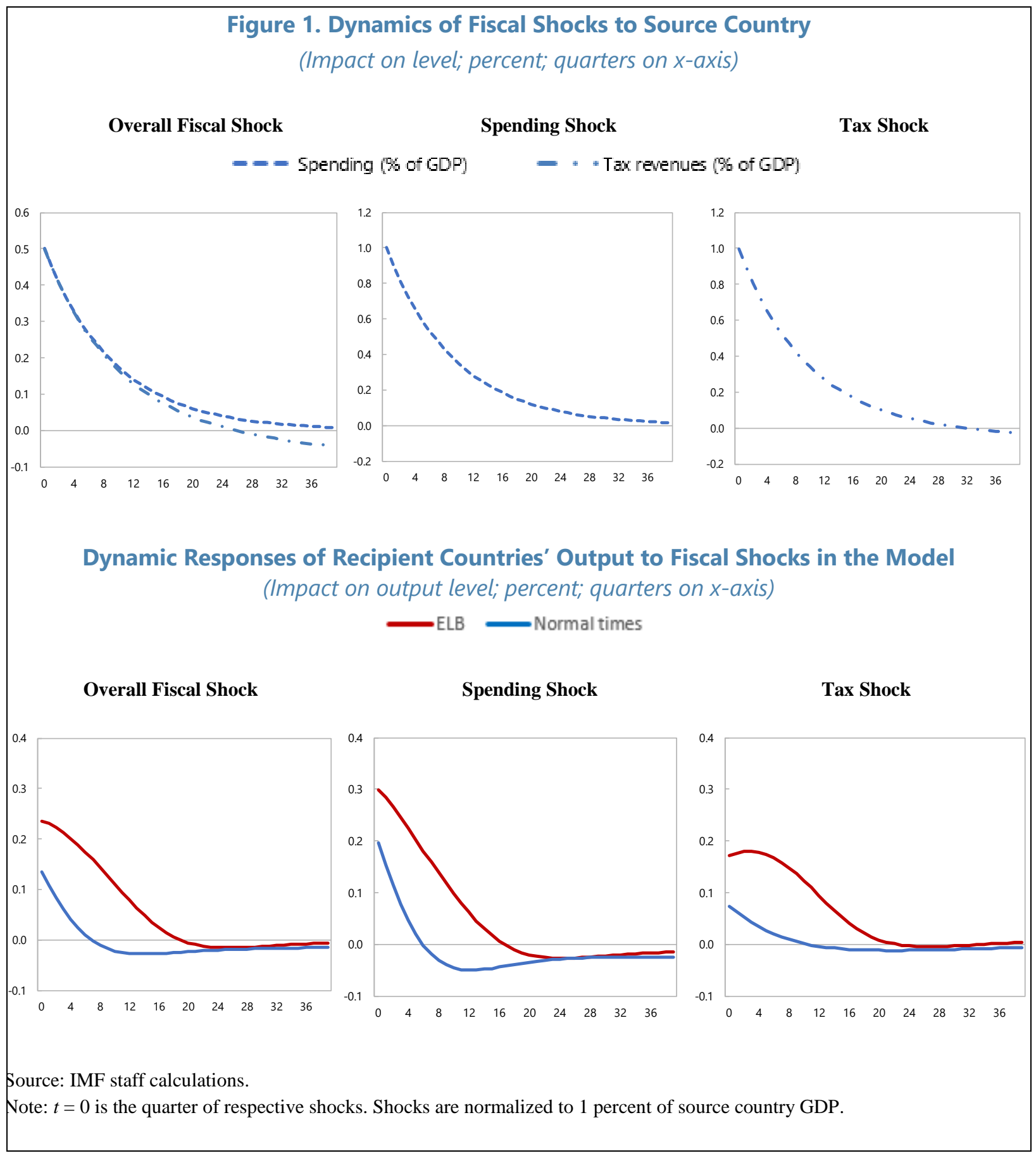

To illustrate the role played by the effective lower bound in cross-border transmission of fiscal shocks - that is, the difference in responses of recipient-country output componentswe conduct a simulation showing the effects of an overall fiscal shock. ${ }^{6}$ Shown in Figure 2, the response of output in the source country following the fiscal stimulus is positive, but less

\footnotetext{
${ }^{6}$ The transmission is qualitatively similar when the fiscal expansion is based only on spending or only on tax revenues. These scenarios are available upon request.
} 
Figure 2. Dynamic responses to overall fiscal shock in Source: normal times vs effective lower bound in recipient country (Percent of output unless noted otherwise; quarters on $x$-axis)

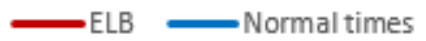

1. Recipient GDP

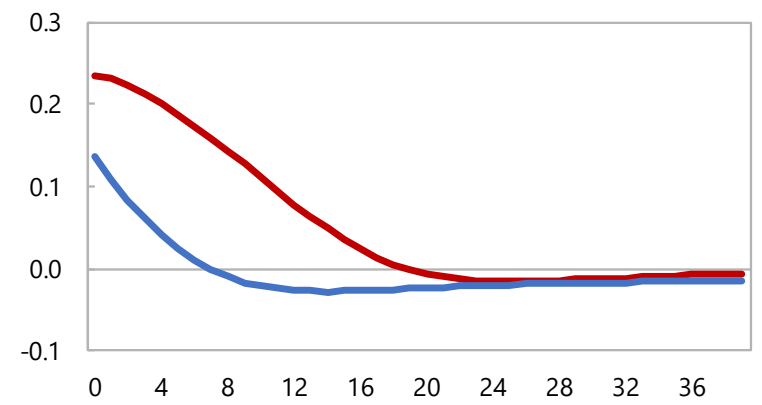

3. Recipient Nominal Interest Rate (percentage points)

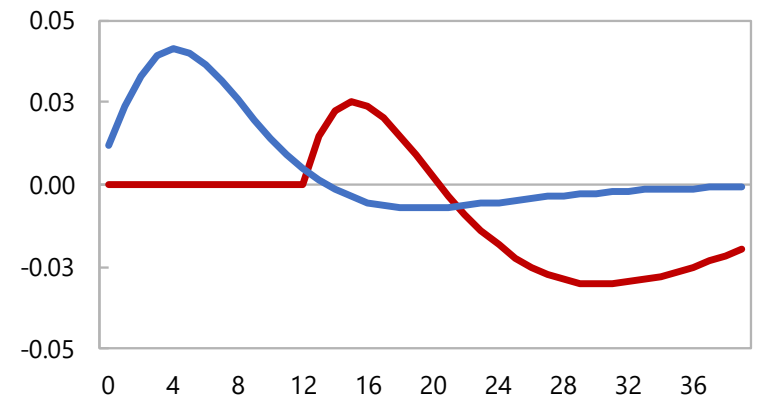

5. Recipient Consumption

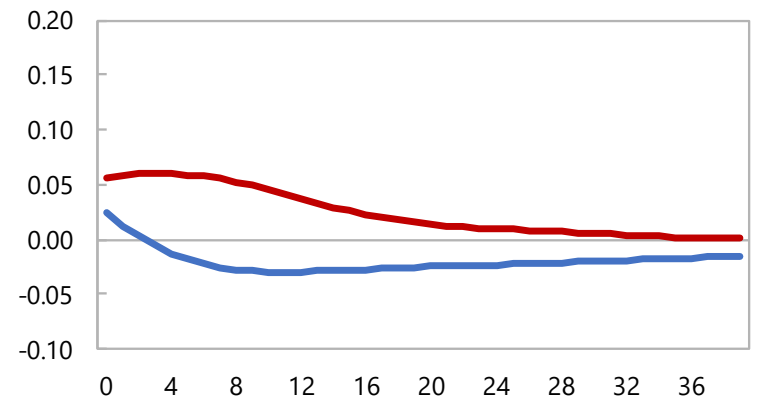

7. Recipient Bilateral Exports

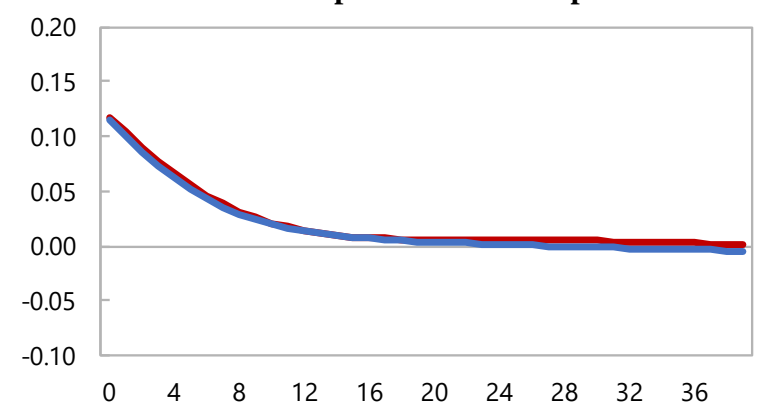

2. Source GDP

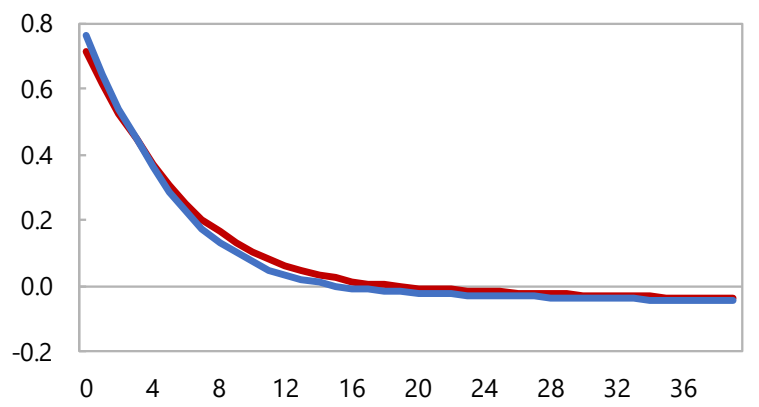

4. Recipient Real Interest Rate (percentage points)

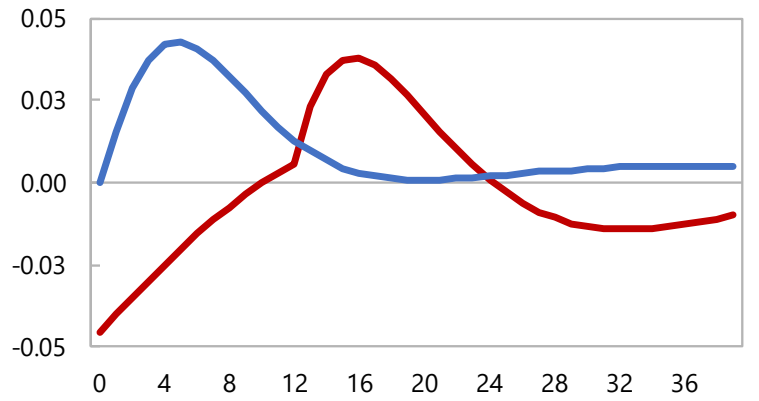

6. Recipient Investment

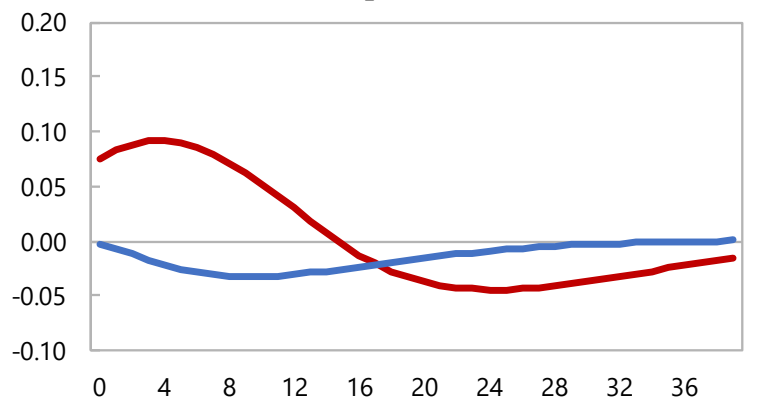

8. Recipient Bilateral Imports

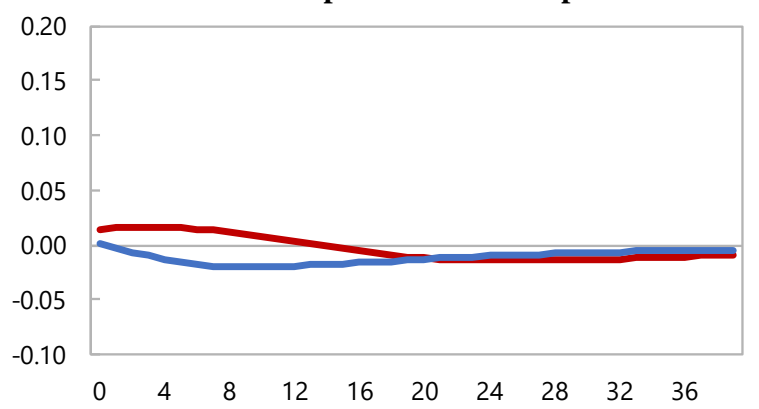

Source: IMF staff estimates.

Note: Normal times $=$ no effective lower bound. $\mathrm{t}=0$ is the quarter of shock. Responses to an overall fiscal shock normalized to 1 percent of source-country GDP. 
than one percent of its GDP, implying that the multiplier from the increased deficit is less than one. In response to this impulse, inflation in the source country increases, prompting an increase in interest rates (not shown). ${ }^{7}$

The transmission of the fiscal shock to the recipient economy differs markedly depending on whether the shock is offset by countercyclical monetary policy. In normal times, faced with a positive external demand shock, the recipient country's exports increase, as does inflation, prompting an increase in interest rates, raising the cost of current-period consumption and investment. The subsequent fall in domestic absorption reduces the overall response of output. By contrast, when the recipient economy is operating at the effective lower bound, the inflationary effect of the external shock — which is the same magnitude as in the normaltimes scenario-reduces real interest rates and boosts consumption and investment. The central bank accommodates the shock, as it delivers a boost to output that cannot otherwise be achieved at the effective lower bound. ${ }^{8}$ The response of investment is approximately 4 times stronger than that of consumption, and the stronger response of the recipient country's domestic absorption results in an overall impact on output that is approximately 2.5 times larger than in normal times. As the simulation assumes that the effective lower bound-and the negative shock which generates it-lasts only for three years, the central bank eventually raises interest rates to bring down inflation. These scenarios suggest that the ability or willingness of monetary policy to respond to external shocks plays a major role in both the size and composition of the output response in the recipient economy. ${ }^{9}$

\section{EMPIRICAL APPROACH AND DATA}

As discussed above, having analyzed predictions about the cross-border transmission of fiscal shocks using a theoretical model, we now turn to test them by estimating spillovers from fiscal shocks on output and its components under different monetary policy conditions, using fiscal shocks from five major economies-France, Germany, Japan, the United Kingdom and the United States—and a broad sample of recipient countries.

\section{A. Identification of fiscal shocks}

We use the structural vector auto-regression (SVAR) methodology of Blanchard and Perotti (2002) for identification of government spending and tax revenue shocks, which relies on

\footnotetext{
${ }^{7}$ Outcomes in the source do not change materially when the response of monetary policy in the recipient is constrained as compared to normal times.

${ }^{8}$ If instead we considered a negative external fiscal shock, the central bank would be unable to offset the shock by providing more stimulus due to the effective lower bound constraint, and thus spillovers would also be amplified.

${ }^{9}$ Performing the same exercise for different states of monetary policy in the source country increases the size of its own output multiplier - and hence demand for exports and the size of spillovers — but otherwise has no impact on how the shock is transmitted to the recipient country. Results for this exercise are available from the authors upon request.
} 
two identifying assumptions. First, it assumes that discretionary fiscal policy does not respond contemporaneously to unexpected changes in output, even though output can respond contemporaneously to fiscal variables. Second, it uses information from outside the model to calibrate the contemporaneous automatic response of tax revenues to output (the tax elasticity). The contemporaneous automatic response of government spending to changes in output is assumed to be zero in quarterly data due to policy decision and implementation lags. Together, these assumptions are equivalent to an ordering restriction in the VAR, where innovations in output are placed after innovations in the fiscal variables, with additional conditioning information given by the tax elasticity. ${ }^{10}$

A key advantage of our baseline methodology is that it allows for comprehensive coverage and consistent joint identification of revenue and spending shocks of positive and negative signs across all source countries. In addition, the use of quarterly data-by increasing the degrees of freedom - also allows us to focus on the post-2000 period and avoid possible structural breaks related to increasing trade openness or economic integration across countries, such as the introduction of the euro. As noted in Blanchard and Perotti's original paper, possible implementation lags imply that structurally identified shocks could be subject to a fiscal foresight problem (see also Ramey 2011, Leeper, Richter, and Walker 2012; Leeper, Walker, and Yang 2013). While this is likely to be relevant to study the behavior of forward-looking variables — such as the exchange rate or interest rates - there is some evidence that fiscal foresight might not present a critical issue for assessing the impact of fiscal actions on relatively slow-moving variables, such as activity. Specifically, Perotti (2014) finds that estimated fiscal multipliers for US defense-spending shocks are little changed between a standard SVAR specification and an expectations-augmented VAR specification which incorporates information from forecasts of future spending. To verify that our baseline results are not biased by fiscal foresight issues, we do robustness checks using shocks based on forecast errors.

\section{B. Econometric specification}

The response of the recipient country's output to a fiscal shock abroad is estimated using the local projections method of Jorda (2005), as in Auerbach and Gorodnichenko (2013). This approach is particularly useful as it allows us to partition the sample and estimate spillovers in different states of the economy. Moreover, the method is more robust to misspecification of the data-generating process than a VAR, for which the misspecification error, if present, is compounded at each horizon of the impulse response.

The specification at time horizon $h$ (for $h=0, \ldots, H$ ) is given by

${ }^{10}$ Appendix B provides a more detailed overview of our shock-identification approach. 


$$
\frac{Y_{i, t+h}-Y_{i, t-1}}{Y_{i, t-1}}=\alpha_{h} \frac{\text { Shock }_{i t}}{Y_{i, t-1}}+\sum_{l=1}^{L} \beta_{h l}^{\prime} X_{i, t-l}+\theta_{h i}+\mu_{h t}+\varepsilon_{i h t}
$$

where $Y_{i t}$ is real GDP in recipient country $i$ at quarter $t$, Shock $_{i t}$ is the foreign fiscal shock facing country $i$ at time $t$ (to be specified below), and $X_{i t}$ is a vector of control variables including lags of the fiscal shock, lags of GDP growth, and lags of external demandmeasured as a weighted average of trading partner growth rates (we choose the number of lags $L=4$ but results are robust to using different lag structures). ${ }^{11} \theta_{h i}$ and $\mu_{h t}$ capture the country and time fixed effects. As the foreign fiscal shock $S h o c k_{i t}$ is expressed in units of recipient-country GDP for the panel estimation, the coefficient $\alpha_{h}$ is analogous to a domestic multiplier of an external demand shock (Hall 2009; Barro and Redlick 2011). The impulse response for $H$ periods is constructed from a sequence of estimates $\left\{\alpha_{h}\right\}_{h=0}^{H}$.

The fiscal shock—Shock ${ }_{i t}$ — combines country-specific shocks from the five source economies, weighting their relative importance using trade links with recipient countries. ${ }^{12}$ Specifically, the fiscal shock facing recipient economy $i$ at time $t$ is given by

$$
\operatorname{Shock}_{i t}=\sum_{j=1}^{5} \frac{M_{i j, t-1}}{M_{j, t-1}} \frac{s_{j t} E_{j, t-1}}{E_{i, t-1}}
$$

where $j$ denotes source country, $M_{i j t}$ is country $j$ 's goods imports from country $i$ at time $t$, $M_{j t}$ is total goods imports by country $j, s_{j t}$ is the identified fiscal shock in country $j$ (in its own currency real terms), and $E_{j t}$ is country $j$ 's U.S. dollar real exchange rate. Thus, the term $s_{j t} E_{j, t-1} / E_{i, t-1}$ equals the real monetary value of the fiscal shock emanating from country $j$ converted into units of recipient country i's currency. This is then scaled by the trade exposure between country $i$ and country $j\left(M_{i, j, t-1} / M_{j, t}\right)$, which captures the relative importance of recipient country $i$ as a supplier of the source country's imports. ${ }^{13}$ Finally, the weighted shocks are added up across the five source countries.

The working assumption behind the construction of the shock is that fiscal policy is transmitted primarily through trade. ${ }^{14}$ All else equal, recipient countries with tighter trade linkages to the source would be expected to receive larger demand shocks for their exports. Combining shocks from all source economies allows us to use critical information about the

\footnotetext{
${ }^{11}$ Results are robust to the inclusion of additional control variables, including short-term interest rates and domestic fiscal policies in recipient countries. Further details are available in Appendix C.

12 The estimated fiscal shocks are uncorrelated across countries.

${ }^{13}$ Bilateral trade data are available for trade in goods only.

${ }^{14}$ This does not preclude spillovers through other channels, since our estimates capture the overall response of recipient country GDP. However, the use of a trade-driven weighting scheme may result in some bias of the estimates in situations where other channels are not proportional to trade-for example, if a recipient country's financial exposure to a source country differs markedly from its trade exposure, although these cases are likely limited.
} 
variability of shocks coming from major economies - trading patterns indicate that any recipient country potentially receives shocks from more than one source country at any point in time.

While our baseline specification in (1) expresses fiscal shocks in terms of recipient-country GDP — which is necessary to combine shocks from different sources-for ease of interpretation of the economic magnitude and comparability with the model simulation results, our empirical estimates of spillovers are rescaled, and presented with shocks normalized to an average 1 percent of GDP across source countries. This requires re-scaling the spillover coefficient $\left(\alpha_{h}\right)$ from our panel results using relative GDP levels and trade links as follows:

$$
\begin{gathered}
\text { Spillover }^{h}=\frac{\sum_{i, j} \text { Spillover }_{i, j}^{h}}{N_{i} N_{j}} \\
\text { where Spillover } \\
i, j \\
=\alpha_{h} \text { Shock }_{j} \frac{M_{i, j}}{M_{j}} \frac{Y_{j}}{Y_{i}}
\end{gathered}
$$

and $S_{h o c k}$ is the source-country shock as percent of its own GDP, assumed to be 1 percent for all our exercises. This shock is then weighted as in our baseline model, using the recipient country's share of source country's total imports $M_{i, j} / M_{j}$. To apply the spillover coefficient $\left(\alpha_{h}\right)$ to this weighted shock, we need to express it in units of recipient-country GDP, i.e. multiply by the ratio $Y_{j} / Y_{i}$, which captures the relative size of source and recipient-country GDP_-both measured in real U.S. dollars. Then, the average value of Spillover ${ }_{i, j}^{h}$ is taken across all source-recipient country pairs (of which there are $N_{i} * N_{j}$ ).

We use the term spillovers to refer to a recipient country's GDP response to the initial fiscal shock at the source, i.e. a point estimate of the IRF. Our approach does not estimate cumulative multipliers, as the aggregation of shocks across source countries makes this infeasible.

To examine how spillovers vary with the state of the recipient economy, we estimate a nonlinear version of the baseline specification, in which we partition the shock as well as the control variables according to the level of the short-term interest rate. Thus, following Auerbach and Gorodnichenko (2013), we adapt the baseline specification from equation (1) in the following way:

$$
\begin{array}{r}
\frac{Y_{i, t+h}-Y_{i, t-1}}{Y_{i, t-1}}=\alpha_{1 h} I_{i, t-1} \frac{\text { Shock }_{i t}}{Y_{i, t-1}}+\alpha_{2 h}\left(1-I_{i, t-1}\right) \frac{\text { Shock }_{i t}}{Y_{i, t-1}} \\
+\sum_{l=1}^{4} \beta_{1 h l}^{\prime} I_{i, t-1} X_{i, t-l}+\sum_{l=1}^{4} \beta_{2 h l}^{\prime}\left(1-I_{i, t-1}\right) X_{i, t-l}+\theta_{h i}+\mu_{h t}+\varepsilon_{i h t}
\end{array}
$$


where $I_{i, t}$ takes the values of either 1 or 0 , indicating the state in recipient country $i$ in period $t$. We consider two different states for the ability of monetary policy to respond to shocksinterest rates near the $\operatorname{ELB}\left(I_{i, t}=1\right)$ and normal times $\left(I_{i, t}=0\right)$, with associated spillovers captured by coefficients $\alpha_{1 h}$ and $\alpha_{2 h}$ respectively. More information on how these states are determined is provided in section 4 .

\section{Data}

To identify fiscal shocks, we construct a database of quarterly government spending, tax revenues, and output for the five source countries: France, Germany, Japan, the United Kingdom and the United States. Our definition of government spending is the sum of government consumption and investment excluding transfers. On the revenue side, we use tax revenues where available and total government revenues in cases where quarterly tax revenue data are absent or patchy (e.g., Japan). ${ }^{15}$ The three series—spending, tax revenues, and output-are seasonally adjusted, converted into per capita real terms, and expressed in logarithms before entering the VAR specification. The starting point of the sample period differs across countries depending on data availability, ranging from 1980Q1 for the United States to 1995Q1 for Japan.

For the spillover analysis, we use a broad sample of 55 recipient economies representing almost 85 percent of global output (on a purchasing power parity basis). The model is estimated using quarterly data for the period 2000Q1-2016Q3. Quarterly data include series on real output, consumption, investment, exports/imports, bilateral goods exports/imports, and external demand collected from multiple data sources. Before entering the regressions, variables with notable trends over the sample period were detrended using country-specific linear trends. In addition, outliers were removed; that is, observations with quarter-overquarter GDP growth rates higher than 10 percent or lower than -10 percent in any given quarter (effectively very few observations). More details about the data and sample are provided in Appendix A.

\section{EMPIRICAL RESULTS}

\section{A. Baseline results}

We find significant spillovers from fiscal shocks. Figure 3 shows the estimated output response to a foreign fiscal shock in an average recipient country over eight quarters. A shock to the fiscal balance-henceforth referred to as the overall fiscal shock-is constructed as a shock to government spending minus a shock to tax revenues, such that a positive shock implies a reduction in the source country's fiscal balance. An overall fiscal shock of 1

\footnotetext{
${ }^{15}$ In cases where both tax and total revenues are available, shocks identified using the two revenue measures are very highly correlated. Consistent data on specific tax instruments (e.g., corporate and personal income tax, consumption tax) are generally not available.
} 
percent of average source country GDP would increase average recipient country output by about 0.04 percent on impact, reaching a peak of 0.1 percent around the third quarter after the shock, before starting to dissipate (Figure 3, panel 1). ${ }^{16}$ Spillovers are economically significant and are broadly in line with earlier estimates in the literature (for example, see Beetsma, Klaassen, and Wieland 2006). The baseline result is also robust to including additional controls (e.g., short-term interest rates, output gap, fiscal stance in recipients) in the specification—-see Appendix C for details.

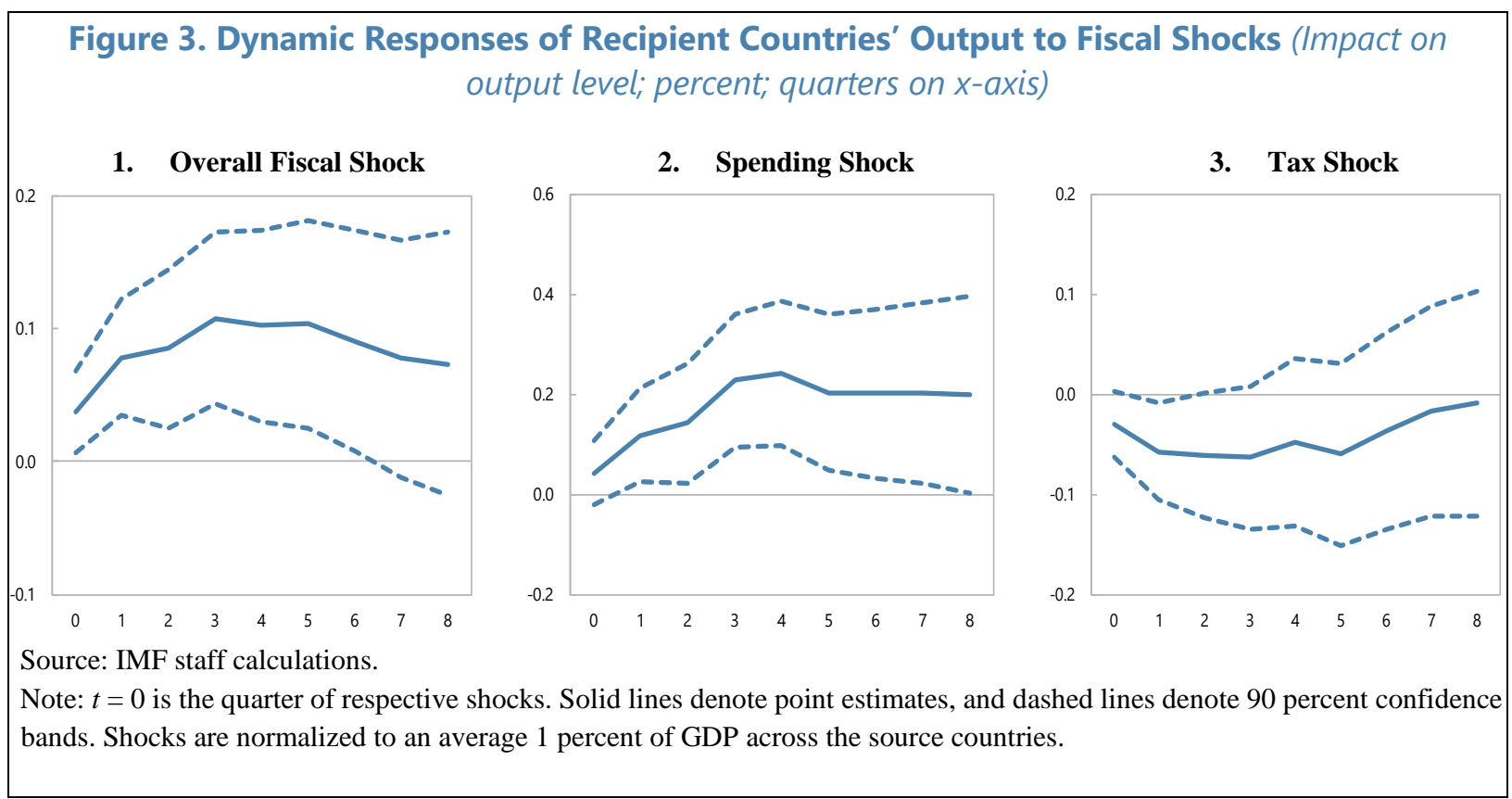

Estimations for specific fiscal instruments show that spillovers from a positive government spending shock are larger (in absolute value), more persistent, and more precisely estimated than those from a positive tax shock of equal size (Figure 3, panels 2 and 3). An increase in foreign fiscal spending of 1 percent of average source country GDP is estimated to increase output in the average recipient by about 0.05 percent on impact, with spillovers stabilizing at around 0.2 percent over a two-year horizon - the impact is statistically significant (95 percent level). The output response to a foreign tax hike of equal size is more muted and short-lived, with output declining by 0.03 percent on impact and reaching a trough of around 0.05 percent by the end of the first year before starting to reverse. ${ }^{17}$ These results are consistent with domestic spending multipliers being generally larger than domestic tax multipliers, as

\footnotetext{
${ }^{16}$ Note that in much of the literature on fiscal spillovers described in section 1 , no distinction is made between the impact on recipient economies due to the initial domestic effect of the shock (the source country fiscal multiplier), and other factors. We follow this convention in reporting our spillover estimates.

${ }^{17}$ Note that the empirical analysis considers an expansionary spending shock, but a contractionary tax shock, whereas the model simulations in section 2 considered expansionary shocks for both instruments (spending increase and tax cut).
} 
prescribed by traditional Keynesian theory and as captured in the state of the art DSGE literature (e.g. Blanchard, Erceg and Linde 2016).

\section{B. Spillovers in Normal Times and near the ELB}

While the spillover estimates from the baseline model are averages across different economic and policy conditions, the analysis in this section shows that there is a large difference between estimates in 'normal times' - that is, when interest rates are not exceptionally lowand those when monetary policy is near the ELB, in line with predictions in structural models. The definition of the ELB is based on the prevailing short-term interest rate in the recipient country: a short-term interest rate below the 25th percentile of the relevant crosscountry distribution is a proxy for monetary policy constrained by the effective lower bound. Different distributions are used for advanced economies and emerging markets. The $25^{\text {th }}$ percentile value for the cross-country distribution is about 0.57 percent for advanced economies and 3.0 percent for emerging markets. Robustness checks to these thresholds are carried out in the following section.

Table 1. Nonlinear Results: ELB vs. Normal Times (Average one-year impact on output; percent)

\begin{tabular}{|c|c|c|c|}
\hline & Overall fiscal shock & Spending shock & Tax shock \\
\hline Baseline & $0.08^{* * *}$ & $0.15^{* *}$ & $-0.05^{*}$ \\
\hline \multicolumn{4}{|l|}{ Recipient economy } \\
\hline Interest rate near effective lower bound & $0.19 * * *$ & $0.3^{* * *}$ & $-0.15^{\star \star}$ \\
\hline Interest rate not near effective lower bound & 0.04 & 0.07 & -0.02 \\
\hline Difference statistically significant? ( $p$-value) & 0.01 & 0.02 & 0.07 \\
\hline
\end{tabular}

Source: IMF staff calculations.

Note: ELB = effective lower bound. Statistical significance $(* 10 \%, * * 5 \%$, ***1\%). Shocks are normalized to an average 1 percent of GDP across the source countries.

The results are presented in Table 1 . Spillovers are indistinguishable from zero in normal times, but can be several times larger when the recipient economy is near the ELB. We find that subject to a 1 percent of GDP overall fiscal shock in an average major advanced economy, the response of recipient country output can be more than four times stronger when its interest rate is exceptionally low as compared to normal times. The difference between responses are statistically significant at the 1, 2, and 7 percent levels of significance for overall, spending, and tax shocks, respectively. This result echoes recent work in the context of domestic multipliers by Ramey and Zubairy (forthcoming), who find some evidence of higher multipliers for US government spending shocks when the economy is at the ELB.

The analysis of components of recipient-country output shed light on the cross-country transmission of fiscal shocks, confirming the role played by monetary policy conditions predicted by model simulations in section 2 (Figure 4). A positive foreign fiscal shock in normal times (blue line) is estimated to moderately raise recipient-country bilateral exports to the source countries. Investment and imports increase marginally-in the first period only- 
and the response of consumption is statistically insignificant. Thus, our findings corroborate the impulse responses from a structural model: spillovers in normal times are small and are driven by exports.

The response of GDP components when interest rates are exceptionally low in recipient countries (green line) is markedly different. Faced with a positive foreign fiscal shock, consumption and particularly investment in a recipient country respond much more strongly when the domestic nominal interest rate is close to the ELB. The difference between the response of investment at the ELB as compared to normal times (on average, for the two-year horizon shown in Figure 4) is strongly statistically significant, with a p-value of 0.016. The same comparison for consumption yields a weaker statistical difference, with a p-value of 0.14 . These results are in line with model simulations, which suggest the strong response of investment and consumption is related to declining real interest rates associated with higher expected inflation. Imports by the recipient from the source countries also respond more strongly when monetary policy accommodates the fiscal shock, in line with the response of domestic demand. However, contrary to what the model simulations predict, we find that exports also react more under the ELB.

\section{Robustness}

To ensure that our results are not driven by the shock identification framework or our definition of the effective lower bound, this section performs two robustness checks. Results show that the baseline results - those which cover the whole sample, and do not differentiate based on monetary conditions - are robust to the use of alternative fiscal shocks based on forecast errors, and non-linear results are robust to alternative definitions of the ELB.

\section{A. Alternative definition of the ELB}

The threshold to define the effective lower bound in advanced economies -0.57 percent, consistent with the $25^{\text {th }}$ percentile of interest-rate observations-is relatively uncontroversial (we could choose an absolute threshold such as 0.5 or 0.75 percent as well, with no meaningful impact on our results). However, the definition of the effective lower bound for emerging markets is less clear. Applying the same criterion as in advanced economies $-25^{\text {th }}$ percentile of the historical short-term rate distribution within each country group-results in a larger value for EMs, about 3 percent. This is in line with generally higher levels of inflation and nominal interest rates historically prevailing in EMs. One argument for the appropriateness of this relatively higher threshold in EMs is that it might be more difficult for central banks operating in an environment of relatively high inflation to bring interest rates close to zero. At the same time, such a high threshold might raise questions about whether our results are driven by it. We run a robustness check using our baseline threshold for AEs (0.57 percent), but a somewhat lower threshold for EMs (1.75 percent) and find that results are generally robust although less statistically significant (Table 3). Although we select an EM threshold of 1.75 for this robustness check, other thresholds close to this value produce similar results. 


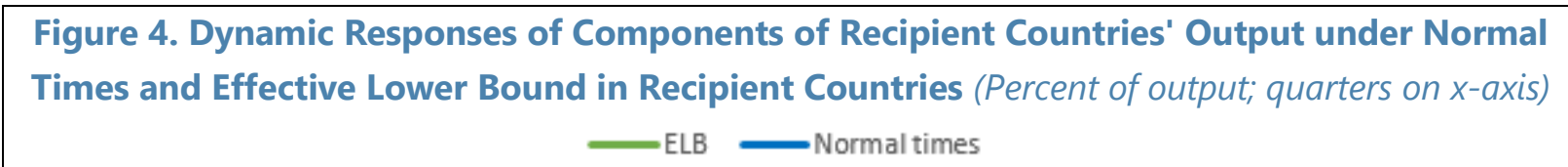

1. Consumption

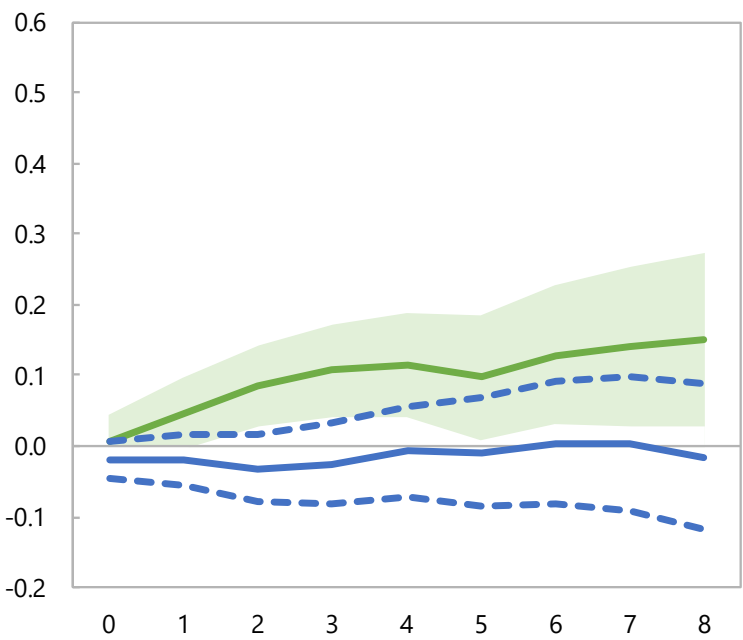

3. Bilateral Exports

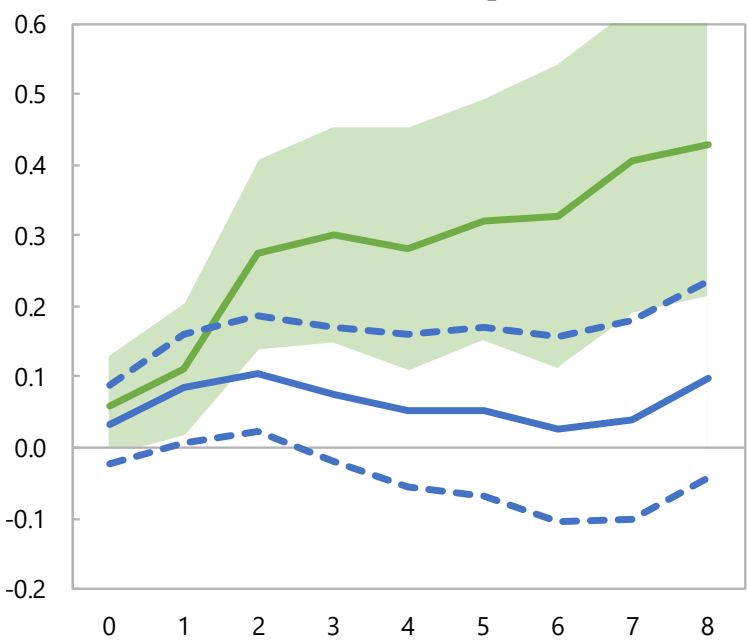

2. Investment

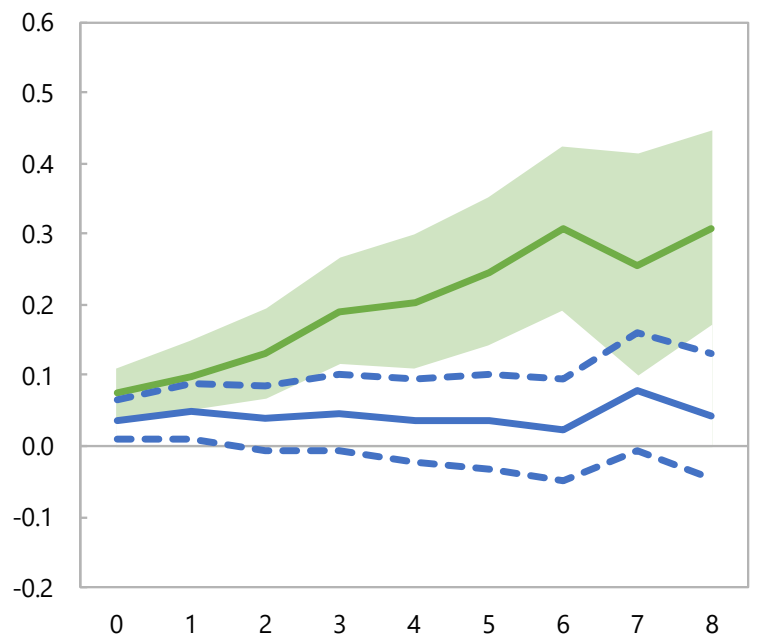

4. Bilateral imports

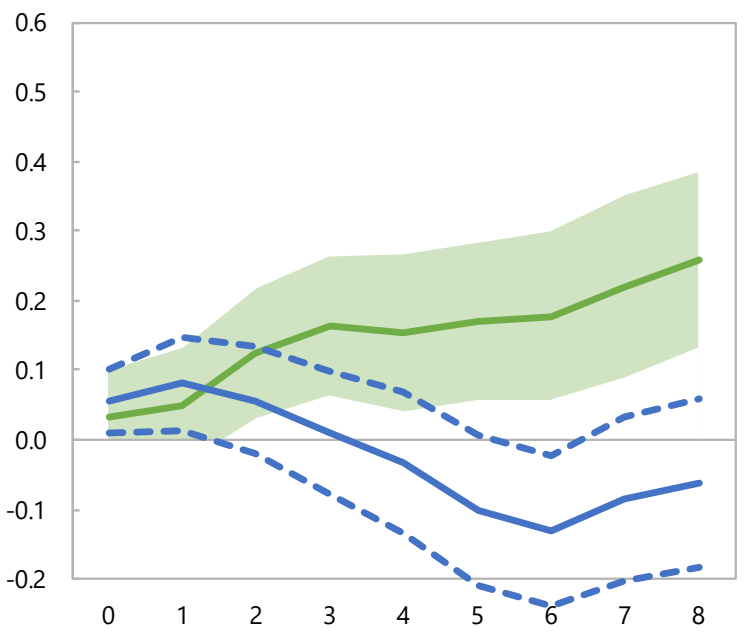

Source: IMF staff estimates.

Note: Normal times $=$ no effective lower bound. $t=0$ is the quarter of shock. Solid green lines denote point estimates under different conditions; dashed green lines denote 90 -percent confidence bands; and solid blue lines represent the unconditional response. Effective lower bound corresponds to short-term interest rates in the bottom 25 percent of crosscountry historical distribution. Responses to an overall fiscal shock normalized to 1 percent of source-country GDP. 
Table 3. Nonlinear Results: ELB vs. Normal Times, Alternative ELB Definition (Average oneyear impact on output; percent)

\begin{tabular}{|lccc|}
\hline Baseline & Overall fiscal shock & Spending shock & Tax shock \\
\cline { 4 - 4 } & $0.08^{* *}$ & $0.15^{* *}$ & $-0.05^{*}$ \\
Recipient economy & & & \\
Interest rate near effective lower bound & & & \\
Interest rate not near effective lower bound & $0.24^{*}$ & 0.30 & $-0.28^{*}$ \\
Difference statistically significant? (p-value) & $0.06^{*}$ & $0.15^{*}$ & -0.03 \\
\hline
\end{tabular}

Source: IMF staff calculations.

Note: ELB = effective lower bound. Statistical significance $(* 10 \%, * * 5 \%, * * * 1 \%)$. Shocks are normalized to an average 1 percent of GDP across the source countries.

\section{B. Alternative shock identification}

This robustness check focuses on the identification of fiscal shocks as forecast errors in the growth rates of government spending or tax revenues - as in Auerbach and Gorodnichenko (2013) and Ramey (2011). Identification relies on the difference between actual government purchases or tax revenues and their forecast in the previous period. This approach captures only unanticipated changes in spending and revenues, as opposed to SVAR shocks, which are based on actual changes in fiscal variables and can be anticipated by agents if they were announced earlier. The presence of such anticipated shocks in theory could bias the estimates because the information set of the econometrician is different from the one of agents.

We rely on real time OECD fiscal projections to construct the forecast error shocks. The data is at annual frequency and the sample covers the period from 2000 to 2012 (after 2012 parts of forecast data are missing). The forecast errors are constructed based on real-time information about expectations and actual data-for each variable $X=\{G, T, Y\}, F E_{t}^{X}=$ $X_{t}-X_{t \mid t-1}^{f}$, where $X_{t}$ is the growth rate of the variable and $X_{t \mid t-1}^{f}$ is the forecast made a period in advanced. A positive forecast error therefore implies higher-than-expected spending and lower-than-expected tax revenue. Following Auerbach and Gorodnichenko (2013), we regress these forecast errors on those of output - to take into account any changes due to surprises in the business cycle - and on lagged macroeconomic variables growth (GDP, deflator, investment, government spending or tax revenues) — to account for the part of the innovation which can be predicted from past observations. The shocks are then constructed as residuals from this regression, converted to levels using base year (2010) levels of expenditures or revenues.

Spillovers are in line with baseline results — significant and larger for spending shocksproviding a strong robustness check (Figure 5). These shocks are constructed using a different methodology and database, and are estimated at a different frequency than the shocks used in our baseline specification. Obtaining similar spillovers using forecast error shocks is reassuring, and suggests fiscal foresight issues do not affect our main results. 
Figure 5. Effects of Spending and Tax Shocks on Recipient Countries' Output: Forecast Errors (Percent; years on $x$-axis)

1. Output Effects of Spending Shock

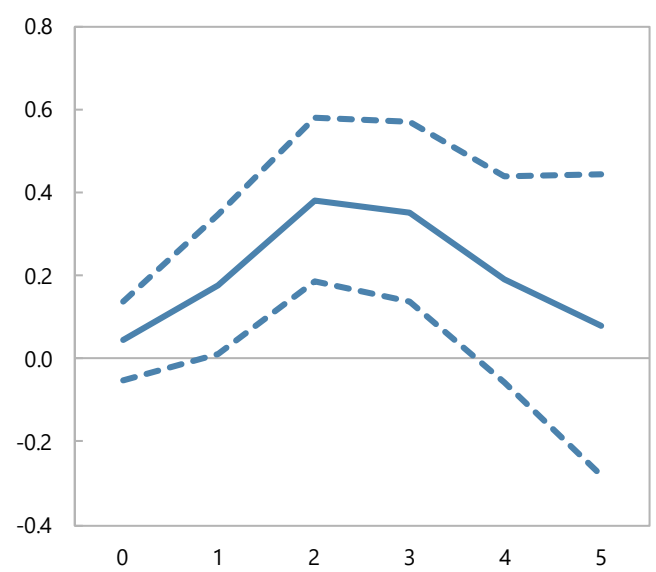

2. Output Effects of Tax Shock

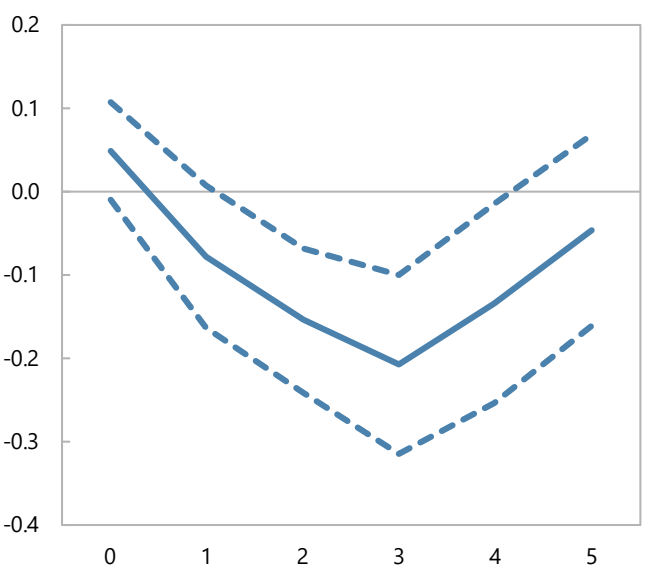

Source: IMF staff calculations.

Note: $t=0$ is the year of respective shocks. Solid lines denote the response to respective shocks, and dashed lines denote 90 percent confidence bands. Effects are estimated based on shocks derived from forecast errors. Shocks are normalized to an average 1 percent of GDP across the source countries.

\section{ConCLUSIONS}

The cross-border transmission of fiscal shocks can be greatly amplified when monetary policy is operating near the effective lower bound, as policymakers may be either unwilling or unable to respond to offset the inflationary and demand effects of the effects of the shocks on domestic demand. This prediction is well captured in standard New Keynesian models such as that of Blanchard, Erceg and Linde (2016), among others. However, there is relatively little empirical evidence in support of this theoretical prediction. We fill that gap by identifying fiscal shocks - both for government spending and tax revenues, for both expansions and consolidations - for five systemic source countries, and estimating spillovers onto a panel of 55 recipient economies under different monetary policy conditions. The results provide strong evidence that spillovers are larger when interest rates are exceptionally low in recipient countries. Examining the drivers of these larger spillovers, we find that the response of domestic demand-investment in particular-is stronger when interest rates in the recipient country are exceptionally low, a finding which is consistent with New Keynesian models. In addition, evidence suggests that government spending shocks have larger spillovers than equally sized (negative) shocks to tax revenues. Applied to the current economic conjuncture, our results suggest that positive cross-border effects from fiscal stimulus may be smaller than in the past, when the effective lower bound constraint on policy rates was binding in many countries. 


\section{REFERENCES}

Auerbach, Alan J., and Yuriy Gorodnichenko 2013. "Output Spillovers from Fiscal Policy.” American Economic Review 103 (3): 141-46.

Barro, Robert J., and Charles J. Redlick. 2011. "Macroeconomic Effects from Government Purchases and Taxes.” Quarterly Journal of Economics 126 (1): 51-102.

Beetsma, Roel, and Massimo Giuliodori. 2006. "What Are the Spill-Overs from Fiscal Shocks in Europe? An Empirical Analysis.” ECB Working Paper Series 325, European Central Bank, Frankfurt.

Beetsma, Roel, Franc Klaassen, and Volker Wieland. 2006. “Trade Spill-Overs of Fiscal Policy in the European Union: A Panel Analysis.” Economic Policy 21 (48): 639-87.

Blanchard, Olivier, Christopher J. Erceg, and Jesper Lindé. 2016. “Jump-Starting the Euro Area Recovery: Would a Rise in Core Fiscal Spending Help the Periphery?” In NBER Macroeconomics Annual 2016, vol. 31, edited by Martin Eichenbaum and Jonathan A. Parker. Forthcoming from University of Chicago Press.

Blanchard, Olivier, and Roberto Perotti. 2002. “An Empirical Characterization of the Dynamic Effects of Changes in Government Spending and Taxes on Output.” Quarterly Journal of Economics 117 (4): 1329-68.

Christiano, Lawrence, Martin Eichenbaum, and Charles Evans. 2005. "Nominal Rigidities and the Dynamic Effects of a Shock to Monetary Policy.” Journal of Political Economy 113 (1): 1-45.

Christiano, Lawrence, Martin Eichenbaum, and Sergio Rebelo. 2011. "When Is the Government Spending Multiplier Large?” Journal of Political Economy 119 (1): 78-121.

Corsetti, Giancarlo, and Gernot J. Müller. 2013. "Multilateral Economic Cooperation and the International Transmission of Fiscal Policy.” NBER Chapters, in: Globalization in an Age of Crisis: Multilateral Economic Cooperation in the Twenty-First Century, 257-297 National Bureau of Economic Research, Inc.

Corsetti, Giancarlo, André Meier, and Gernot J. Müller. 2012. "Fiscal Stimulus with Spending Reversals” The Review of Economics and Statistics, vol. 94(4): 878895.

DeVries, Pete, Jaime Guajardo, Daniel Leigh, and Andrea Pescatori. 2011. “A New ActionBased Dataset of Fiscal Consolidation.” IMF Working Paper 11/128, International Monetary Fund, Washington, DC. 
Elekdag, S., and D. Muir. 2014. "Das Public Kapital: How Much Would Higher German Public Investment Help Germany and the Euro Area?”, IMF Working Paper No. $14 / 227$.

Erceg, Christopher J., and Jesper Lindé. 2013. "Fiscal Consolidation in a Currency Union: Spending Cuts vs. Tax Hikes.” Journal of Economic Dynamics and Control 37 (2): 422-45.

Eggertson, Gauti B. 2011. “What Fiscal Policy is Effective at Zero Interest Rates?” in NBER Macroeconomics Annual 2010, vol 25, 59-112. Cambridge, MA: MIT Press.

Faccini, R., Mumtaz, H. and Surico, P., 2016. “International fiscal spillovers.” Journal of International Economics 99(C): 31-45.

Freedman, C., M. Kumhof, D. Laxton, D. Muir, and S. Mursula, 2010. “Global effects of fiscal stimulus during the crisis” Journal of Monetary Economics 57 (5): 506526.

Goujard, Antoine. 2017. “Cross-Country Spillovers from Fiscal Consolidations.” Fiscal Studies 38 (2): 219-67.

Hall, Robert E. 2009. "By How Much Does GDP Rise If the Government Buys More Output?” Brookings Papers on Economic Activity 40 (Fall): 183-249.

Hebous, S., and T. Zimmerman. 2013. “Cross-Border Effects of Fiscal Consolidations: Estimates Based on Narrative Records” CESifo Working Paper no. 4311

In’t Veld, J. 2013. "Fiscal Consolidations and Spillovers in the Euro Area Periphery and Core.” Economic Papers No. 506, European Commission, Brussels.

Jordà, Òscar. 2005. "Estimation and Inference of Impulse Responses by Local Projections.” American Economic Review 95 (1): 161-82.

Leeper, E. M., A. W. Richter, and T. B. Walker. 2012. "Quantitative Effects of Fiscal Foresight.” American Economic Journal: Economic Policy 4(2): 115-144.

Leeper, E. M., T. B. Walker, and S. S. Yang. 2013. "Fiscal Foresight and Information Flows.” Econometrica 81(3): 1115-1145. Econometric Society.

Nicar, Stephen B. 2015. “International Spillovers from U.S. Fiscal Policy Shocks.” Open Economies Review 26 (5): 1081-97.

Perotti, Roberto. 2014. "Defense Government Spending is Contractionary, Civilian Government Spending is Expansionary.” NBER Working Paper 20179, National Bureau of Economic Research, Cambridge, MA.

Ramey, Valerie A. 2011. "Identifying Government Spending Shocks: It's all in the Timing.” Quarterly Journal of Economics 126 (1): 1-50. 
Ramey, Valerie A, and Sarah Zubairy. Forthcoming. "Government Spending Multipliers in Good Times and in Bad: Evidence from U.S. Historical Data,” Journal of Political Economy.

Romer, Christina D., and David H. Romer, 2010. "The Macroeconomic Effects of Tax Changes: Estimates Based on a New Measure of Fiscal Shocks” American Economic Review, 100(3): 763-801.

Smets, F., Wouters, R., 2003. An estimated dynamic stochastic general equilibrium model of the Euro Area. Journal of the European Economic Association, 1 (5), 11231175.

Smets, F, Wouters, R., 2007. Shocks and frictions in the US business cycles: A Bayesian DSGE approach. American Economic Review 97 (3), 586-606.

Woodford, Michael. 2011. "Simple Analytics of the Government Expenditure Multiplier." American Economic Journal: Macroeconomics 3 (1): 1-35. 


\section{APPENDIX}

\section{A. Data}

\section{Data for shock identification}

Quarterly fiscal data used in shock identification for five shock-emitting (source) countries were collected from national statistical bureaus, either directly or via Haver Analytics. ${ }^{18}$ Quarterly real government spending and tax revenue data used in constructing fiscal shocks were all expressed in local currency units, seasonally adjusted, and annualized for the sample period of 2000:Q1-2016:Q3. Government spending was calculated as the sum of quarterly general government consumption and general government gross fixed capital formation from national accounts. For tax revenue, quarterly general government total tax income was used, except for Japan. Data sources for each country are listed in Annex Table A1.

\section{Data for spillover analysis}

Quarterly data from 55 recipient countries for 2000:Q1-2016:Q3 include series on real output, consumption, investment, exports/imports, bilateral good exports/imports, external demand, short-term interest rates, and output gaps, collected from multiple data sources. Data sources for each series are listed in detail in Annex Table A2, followed by a list of all the countries in the sample in Annex Table A3.

\section{Data Description}

- $\quad$ Real GDP, consumption, investment: Quarterly real levels were rebased to 2010 prices, expressed in local currency units, seasonally adjusted and annualized. Investment data refer to gross fixed capital formation.

- $\quad$ Exports/imports: Quarterly real levels were rebased to 2010 prices, expressed in local currency units, seasonally adjusted and annualized. Data from national accounts were taken from Haver Analytics and refer to total exports/imports of goods and services.

- Bilateral goods exports/imports: Bilateral weights were calculated using bilateral exports/imports of goods among 55 recipient countries and 5 source countries in the sample (55 x $5=275$ pairs). For each source-recipient country pair, the average between reported values of both countries was taken.

- $\quad$ External demand: This was calculated as a weighted sum of partner countries' real growth based on bilateral export weights.

\footnotetext{
${ }^{18}$ France, Germany, Japan, United Kingdom, United States.
} 
- $\quad$ Short-term interest rate: The three-month London interbank offered rate (LIBOR) and three-month Treasury bill rate were used. For more comprehensive country and historical coverage, policy, deposit, and target rates were used where three-month LIBOR and Treasury bill data were not available.

- $\quad$ Output gap: The quarterly output gap was first calculated as the gap between real output and potential output, estimated by the Hodrick-Prescott filter. Then, to reconcile any potential difference between the estimated output gap and annual output gap numbers published in the IMF's World Economic Outlook (WEO), the Denton proportional benchmarking method was used. This method both preserved the seasonality observed from quarterly estimated output gap series and matched the data published in the WEO when converted to annual basis.

Before entering the regressions, variables with notable trends over the sample period were detrended using country-specific linear trends. ${ }^{19}$ In addition, outliers were removed; that is, observations with quarter-over-quarter GDP growth rates higher than 10 percent or lower than -10 percent in any given quarter (very few observations).

\footnotetext{
${ }^{19}$ Empirical estimates of spillovers are robust to an alternative specification in which variables with trends are not detrended.
} 


\section{Annex Table A1. Data Sources for Quarterly Fiscal Data by Source Country}

\begin{tabular}{|c|c|c|c|c|}
\hline Country & Fiscal Data & Data Source & Seasonal Adjustment & Note \\
\hline \multirow[t]{2}{*}{ France } & Government spending & Eurostat $^{1}$ & SWDA by source & $\begin{array}{l}\text { Sum of government final } \\
\text { consumption and GFCF }\end{array}$ \\
\hline & Tax revenue & Eurostat $^{1}$ & SWDA by source & $\begin{array}{l}\text { Current taxes on income } \\
\text { and wealth, excluding } \\
\text { social contributions }\end{array}$ \\
\hline \multirow[t]{2}{*}{ Germany } & Government spending & Deutsche Bundesbank & SWDA by source & $\begin{array}{l}\text { Sum of government final } \\
\text { consumption and GFCF }\end{array}$ \\
\hline & Tax revenue & Eurostat $^{1}$ & & \\
\hline \multirow[t]{2}{*}{ Japan } & Government spending & Cabinet Office of Japan & SAAR by source & $\begin{array}{l}\text { Sum of government final } \\
\text { consumption and GFCF }\end{array}$ \\
\hline & Government total revenue & $\begin{array}{l}\text { Ministry of Finance and } \\
\text { Cabinet Office }\end{array}$ & $\begin{array}{l}\text { X-12-ARIMA by IMF } \\
\text { staff }\end{array}$ & $\begin{array}{l}\text { Extrapolated using Denton } \\
\text { method }\end{array}$ \\
\hline \multirow[t]{2}{*}{ United Kingdom } & Government spending & $\begin{array}{l}\text { Office for National } \\
\text { Statistics }\end{array}$ & $\begin{array}{l}\text { Seasonally adjusted by } \\
\text { source }\end{array}$ & $\begin{array}{l}\text { Sum of government final } \\
\text { consumption and GFCF }\end{array}$ \\
\hline & Tax revenue & Eurostat $^{1}$ & & \\
\hline \multirow[t]{2}{*}{ United States } & Government spending & $\begin{array}{l}\text { U.S. Bureau of Economic } \\
\text { Analysis }\end{array}$ & $\begin{array}{l}\text { Seasonally adjusted by } \\
\text { source }\end{array}$ & $\begin{array}{l}\text { Sum of government final } \\
\text { consumption and GFCF }\end{array}$ \\
\hline & Tax revenue & $\begin{array}{l}\text { U.S. Bureau of Economic } \\
\text { Analysis }\end{array}$ & $\begin{array}{l}\text { Seasonally adjusted by } \\
\text { source }\end{array}$ & \\
\hline
\end{tabular}

Source: IMF staff compilation.

Note: For government spending, nominal levels were deflated using the GDP deflator if real levels were not directly available from the source. For tax revenue (total revenue for Japan), real levels were calculated by deflating nominal levels using each country's GDP deflator. GFCF = gross fixed capital formation; SAAR = seasonally adjusted and annualized data; SWDA = seasonally and working-day adjusted data; X-12-ARIMA = U.S. Census Bureau software package for seasonal adjustment.

${ }^{1}$ Quarterly nonfinancial accounts for general government database from Eurostat. 


\section{Annex Table A2. Data Sources for Recipient Countries}

\begin{tabular}{|c|c|c|c|c|}
\hline Series & Data Sources & Estimation & $\begin{array}{l}\text { Countries Missing } \\
\text { Data }\end{array}$ & Note \\
\hline Real Output & WEO; Haver Analytics & $\begin{array}{l}\text { Rebased to 2010; } \\
\text { deflated using GDP } \\
\text { deflator }\end{array}$ & None in the sample & $\begin{array}{l}\text { Seasonally adjusted, } \\
\text { annualized, in national } \\
\text { currency }\end{array}$ \\
\hline $\begin{array}{l}\text { Real Consumption, } \\
\text { Investment, Exports, } \\
\text { Imports }\end{array}$ & Haver Analytics & $\begin{array}{l}\text { Rebased to 2010; } \\
\text { deflated using } \\
\text { respective deflators for } \\
\text { each country and } \\
\text { variable }\end{array}$ & Vietnam & $\begin{array}{l}\text { Seasonally adjusted, } \\
\text { annualized, in national } \\
\text { currency; data from } \\
\text { national accounts }\end{array}$ \\
\hline $\begin{array}{l}\text { Bilateral Goods } \\
\text { Exports/Imports }\end{array}$ & DOTS & $\begin{array}{l}\text { Average between values } \\
\text { reported by the reporter } \\
\text { and partner countries }\end{array}$ & None in the sample & $\begin{array}{l}\text { Original data at monthly } \\
\text { frequency, aggregated } \\
\text { by sum }\end{array}$ \\
\hline External Demand & $\begin{array}{l}\text { WEO; DOTS; Haver } \\
\text { Analytics }\end{array}$ & $\begin{array}{l}\text { Export-weighted sum of } \\
\text { partner countries' real } \\
\text { GDP growth }\end{array}$ & None in the sample & $\begin{array}{l}\text { Seasonally adjusted, } \\
\text { quarter over quarter } \\
\text { growth, log difference, } \\
\text { percent }\end{array}$ \\
\hline $\begin{array}{l}\text { Short-Term Monetary } \\
\text { Policy Rate }\end{array}$ & $\begin{array}{l}\text { Bloomberg Finance } \\
\text { L.P.; Haver Analytics }\end{array}$ & $\begin{array}{l}\text { Three-month LIBOR, } \\
\text { three-month Treasury } \\
\text { bill rate, where available }\end{array}$ & $\begin{array}{l}\text { Cyprus, Estonia, } \\
\text { Luxembourg, Slovak } \\
\text { Republic, Uruguay }\end{array}$ & $\begin{array}{l}\text { Policy rate, deposit rate, } \\
\text { target rate used where } \\
\text { LIBOR and treasury bill } \\
\text { rates were not available }\end{array}$ \\
\hline Output Gap & WEO; Haver Analytics & $\begin{array}{l}\text { Gap between real output } \\
\text { and potential output } \\
\text { estimated by HP filter }\end{array}$ & None in the sample & $\begin{array}{l}\text { Denton method used to } \\
\text { match annual output gap } \\
\text { numbers in WEO }\end{array}$ \\
\hline
\end{tabular}

Source: IMF staff compilation.

Note: DOTS = IMF, Direction of Trade Statistics; HP = Hodrick-Prescott; LIBOR = London interbank offered rate; WEO = IMF, World Economic Outlook. 


\section{Annex Table A3. Recipient Countries in Sample}

\begin{tabular}{|l|l|}
\hline Region & Countries (55 total) \\
\hline Africa & South Africa \\
\hline Americas & $\begin{array}{l}\text { Argentina, Brazil, Canada, Chile, Colombia, Costa Rica, Mexico, Peru, } \\
\text { United States, * Uruguay }\end{array}$ \\
\hline Asia & $\begin{array}{l}\text { Australia, China, India, Indonesia, Japan,* Korea, Malaysia, New Zealand, } \\
\text { Philippines, Thailand, Vietnam }\end{array}$ \\
\hline Europe & $\begin{array}{l}\text { Austria, Belgium, Bulgaria, Croatia, Cyprus, Czech Republic, Denmark, } \\
\text { Estonia, Finland, France, }{ }^{*} \text { Germany,* Greece, Hungary, Ireland, Israel, Italy, } \\
\text { Latvia, Lithuania, Luxembourg, Malta, Netherlands, Norway, Poland, } \\
\text { Portugal, Romania, Russia, Slovak Republic, Slovenia, Spain, Sweden, } \\
\text { Switzerland, Turkey, United Kingdom* }\end{array}$ \\
\hline
\end{tabular}

Source: IMF staff compilation.

*Shock-emitting (source) country. Source country is excluded from the set of recipient countries when analyzing fiscal shocks from the same source.

\section{B. Fiscal shock identification}

This appendix provides a brief overview of the SVAR shock identification methodology of Blanchard and Perotti (2002) as applied in this paper.

\section{VAR specification}

The identification of shocks under this methodology involves estimating the following VAR specification:

$$
Y_{t}=A(L, q) Y_{t-1}+U_{t}
$$

where $Y_{t} \equiv\left[T_{t}, G_{t}, X_{t}\right]^{\prime}$ is a vector containing the values of quarterly taxes, spending, and GDP (all in logs of real, per capita terms), $A(L, q)$ is a 4-quarter distributed lag polynomial, and $U_{t} \equiv\left[t_{t}, g_{t}, x_{t}\right]^{\prime}$ is the corresponding vector of reduced-form residuals. We can write:

$$
\begin{gathered}
t_{t}=a_{1} x_{t}+a_{2} e_{t}^{g}+e_{t}^{t} \\
g_{t}=b_{1} x_{t}+b_{2} e_{t}^{t}+e_{t}^{g} \\
x_{t}=c_{1} t_{t}+c_{2} g_{t}+e_{t}^{x}
\end{gathered}
$$

where $e_{t}^{t}, e_{t}^{g}, e_{t}^{x}$ are the mutually uncorrelated structural shocks that we want to recover. For example, equation (B.2) says that unexpected movements in taxes can be due to response to unexpected movements in GDP and response to structural shocks to spending or taxes. 


\section{Identification}

The identification follows three steps:

- The effects of activity on taxes and government spending — captured by the coefficients $a_{1}$ and $b_{1}$-consist of two channels: (i) the automatic responses of these fiscal variables to activity under existing fiscal policy rules, and (ii) discretionary policy change in response to unexpected shocks to activity. The key identifying assumption is that the second channel does not operate with the use of quarterly data due to decision lags (i.e. it takes time for policymakers to realize a shock to GDP and make spending/tax decisions in response). In addition, there is no evidence of any automatic response of spending to activity, and thus $b_{1}=0$. For taxes, the automatic response of tax revenues to activity can be calibrated using the empirically-estimated elasticity of tax revenues with respect to output (or 'tax elasticity', see further below), pinning down $\mathrm{a}_{1}$ coefficient.

- With $\mathrm{a}_{1}$ and $\mathrm{b}_{1}$ pinned down, construct the cyclically-adjusted reduced form tax and spending residuals, $t_{t}^{\prime} \equiv t_{t}-a_{1} x_{t}$ and $g_{t}^{\prime} \equiv g_{t}-b_{1} x_{t}=g_{t}$, which can be used as instruments to estimate $c_{1}$ and $c_{2}$ in a regression of $x_{t}$ on $t_{t}$ and $g_{t}$ since they are not correlated with $\mathrm{e}_{\mathrm{t}}^{\mathrm{x}}$.

- The remaining parameters, $\mathrm{a}_{2}$ and $\mathrm{b}_{2}$, can be estimated under two alternative assumptions: (i) assuming $a_{2}=0$ (taxes do not respond to spending) and estimating $b_{2}$, or (ii) assuming $b_{2}=0$ (spending does not respond to taxes) and estimating $a_{2}$. Both give similar results.

While the identified structural shocks are not very sensitive to the value of tax elasticity used, the domestic tax multiplier is. Blanchard and Perotti (2002) use data on institutional characteristics of the tax system in the US to estimate the elasticity at quarterly frequency, obtaining the number 2.08. Their estimate of the domestic tax multiplier after 8 quarters is 0.72/1.32 depending on the VAR specification. Caldara and Kamps (2012) show that the size of the fiscal multiplier increases in the size of the elasticity, suggesting that careful calibration of this value is important to correctly estimate the size of the multiplier. Mertens and Ravn (2014) propose a new methodology - proxy SVAR, which integrates shocks identified from a narrative approach, such as for example Romer and Romer (2010), into the standard SVAR framework - that allows estimating the size of the elasticity rather than directly assuming it, and find that the underlying value of the elasticity is 3.13 rather than 2.08 for the US. This higher elasticity value reconciles the size of the domestic multiplier typically obtained from structural VARs with the estimates obtained using narrative shocks, where the latter is typically higher.

To estimate the tax elasticities in the five source countries, we follow Mertens and Ravn (2014) and use information on other measures of tax shocks. 
- $\quad$ United States. We use the value of 3.13, which comes from Mertens and Ravn (2014) analysis based on Romer and Romer (2010) shocks and quarterly data.

- United Kingdom. Cloyne (2013) estimates this elasticity for the UK using a new quarterly dataset of narrative tax shocks and arrives at the value of 1.61, which we use in our analysis.

- Germany, France, Japan. For these countries, elasticity estimates are not readily available from the literature, therefore we estimate the elasticity values ourselves. The data on narrative shocks, which could be used in a proxy SVAR, for these countries is scarce. The only available narrative dataset, DeVries and others (2011), has annual frequency and includes only fiscal consolidations, thus not fully capturing all possible tax shocks. Instead, we use the forecast error shocks to complement the SVAR and recover the elasticity estimates. These shocks capture unanticipated tax changes based on OECD forecasts. ${ }^{20}$ The sample for each country is based on availability of forecast error shocks. The resulting values of elasticities vary depending on the exact VAR specification (trend, dummies), and we chose a specific value within the obtained range. The values are 0.7 for Germany, 1.8 for France, and 1.3 for Japan.

\section{Robustness to inclusion of additional control variables}

Baseline results are also robust to the inclusion of additional control variables.

- First, we use the short-term interest rate to control for the stance of recipient-country monetary policy, and the output gap and unemployment rate as measures of slack in recipients. Dynamic responses are presented in Figures C.1-C.3 and confirm that additional control variables do not materially change the baseline results.

- Controlling for domestic fiscal policies in the baseline specification is another important robustness check, however estimating fiscal shocks for 55 recipient economies at quarterly frequency is infeasible because quarterly fiscal data is not available for many countries. Since Eurostat provides fiscal data at quarterly frequency for European countries, we conduct a robustness check for this sub-sample where we control for changes in primary balances (as a percent of GDP) to proxy for the stance of recipientcountry fiscal policy. Since this robustness check is done on a limited sample (European union), we select Germany and France as source countries for this exercise, since shocks from these countries are most relevant for Europe. We find that the results of this robustness check are almost identical to a baseline which omits the stance of recipientcountry fiscal policy (Figure C.4).

\footnotetext{
${ }^{20}$ One potential drawback of using these shocks is that they are only available at annual frequency, meaning that the elasticity should be recovered from a VAR specified on annual data and might not be a good measure for quarterly elasticity. Another potential problem is that forecast error shocks can only capture unanticipated changes in fiscal variables, while anticipated changes can play an important role as well. However, there is no quarterly measure of shocks available for these three countries, nor a measure of anticipated shocks, that we could use in the estimation.
} 


\section{Figure C.1. Dynamic Responses of Recipient Countries' Output to Fiscal Shocks, Controlling for Monetary Policy (Percent; quarters on $x$-axis)}

Controlling for monetary policy

1. Output Effects of Spending Shock

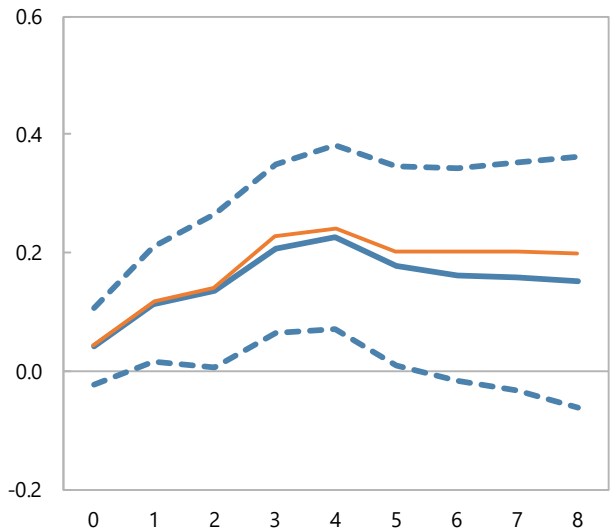

2. Output Effects of Tax Shock

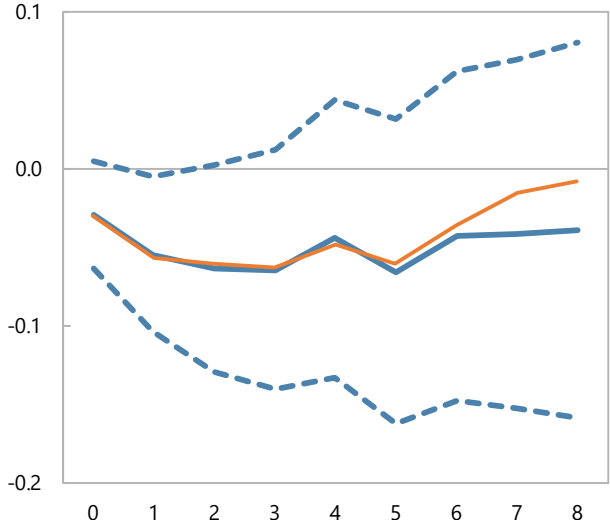

Source: IMF staff calculations.

Note: $t=0$ is the quarter of respective shocks. Solid blue lines denote the baseline response to respective shocks using local projection method; dashed lines denote 90 percent confidence bands; and solid orange lines represent the unconditional response to respective shocks. Shocks are normalized to an average 1 percent of GDP across the source countries.

Figure C.2. Dynamic Responses of Recipient Countries' Output to Fiscal Shocks, Controlling for Output Gap (Percent; quarters on x-axis)

Controlling for output gap

1. Output Effects of Spending Shock

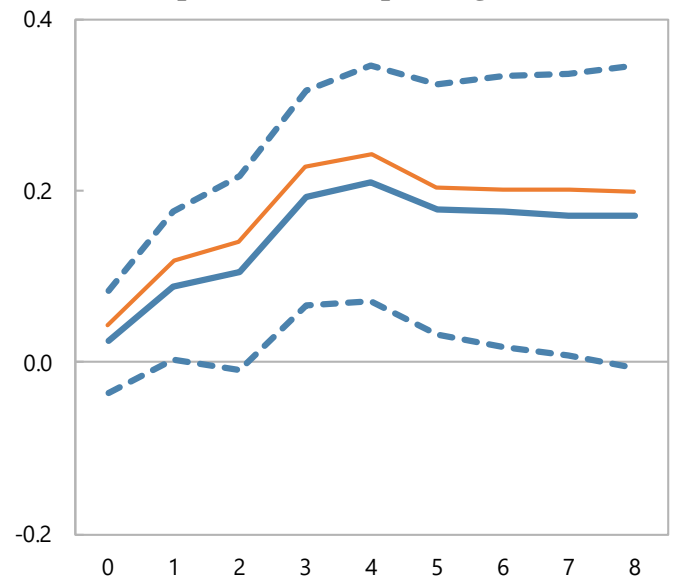

Baseline model

2. Output Effects of Tax Shock

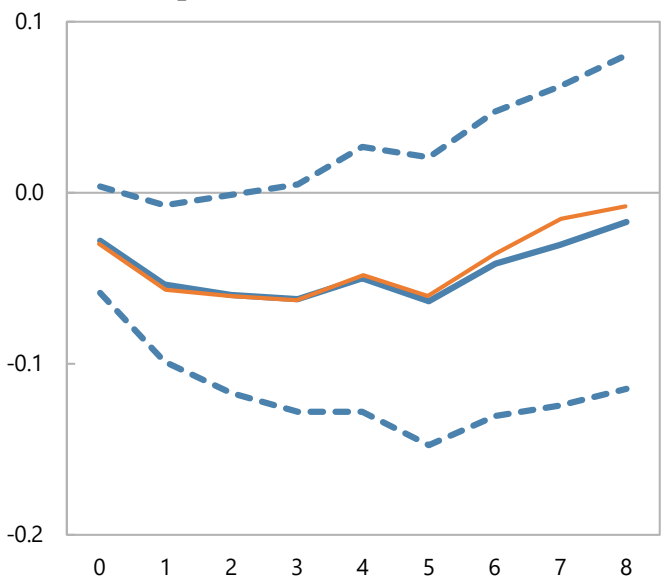

Source: IMF staff calculations.

Note: $t=0$ is the quarter of respective shocks. Solid blue lines denote the baseline response to respective shocks using local projection method; dashed lines denote 90 percent confidence bands; and solid orange lines represent the unconditional response to respective shocks. Shocks are normalized to an average 1 percent of GDP across the source countries. 


\section{Figure C.3. Dynamic Responses of Recipient Countries' Output to Fiscal Shocks, Controlling for Unemployment Rate (Percent; quarters on $x$-axis)}

Controlling for unemployment rate

1. Output Effects of Spending Shock

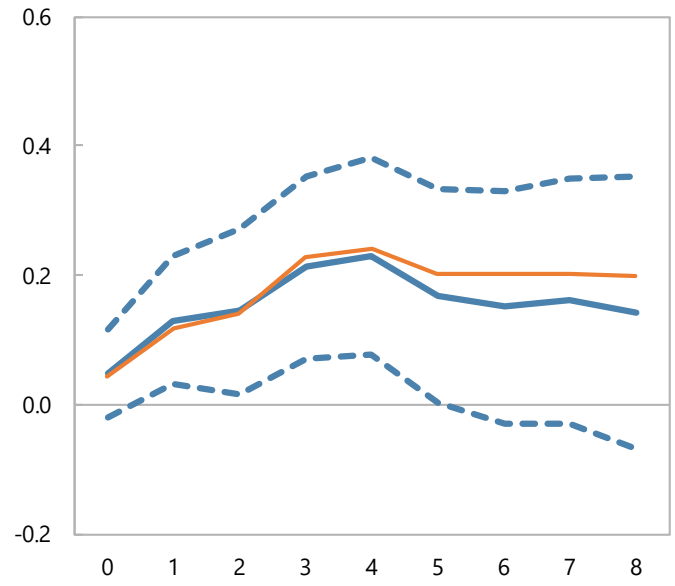

Baseline model

\section{Output Effects of Tax Shock}

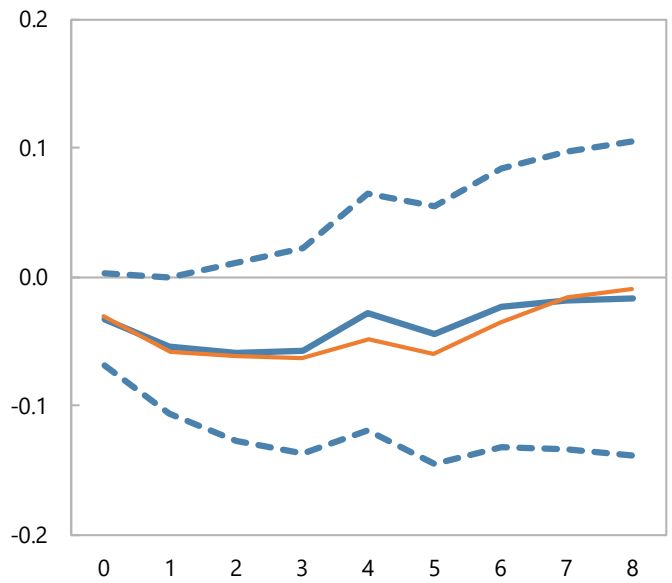

Source: IMF staff calculations.

Note: $t=0$ is the quarter of respective shocks. Solid blue lines denote the baseline response to respective shocks using local projection method; dashed lines denote 90 percent confidence bands; and solid orange lines represent the unconditional response to respective shocks. Shocks are normalized to an average 1 percent of GDP across the source countries.

Figure C.4. Dynamic Responses of Recipient Countries' Output to Fiscal Shocks from Germany and France, Controlling for Recipients' Fiscal Stance (Percent; quarters on x-axis)

Controlling for fiscal stance

\section{Output Effects of Spending Shock}

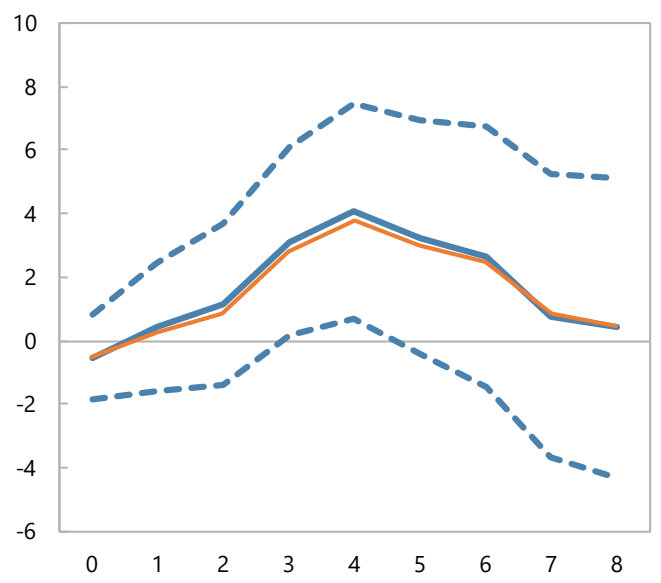

Baseline model

\section{Output Effects of Tax Shock}

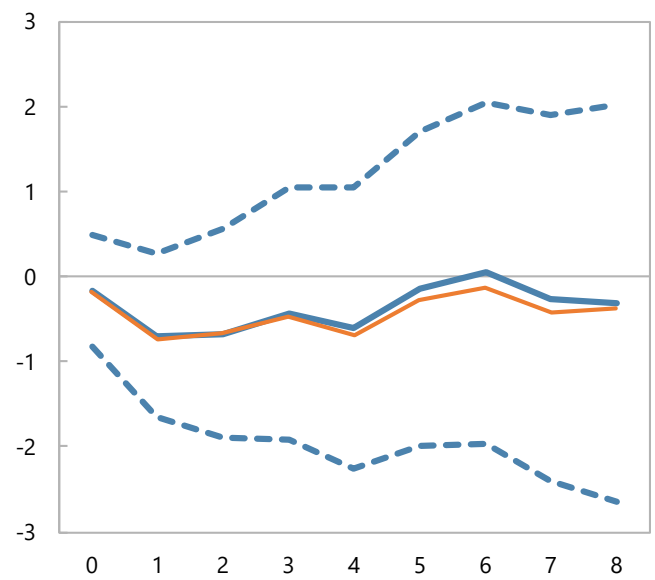

Source: IMF staff estimates.

Note: $t=0$ is the quarter of respective shocks. Solid blue lines denote the response to respective shocks using local projection method, controlling for the change in recipients' primary balance estimated on the (time-varying) European Union sample; dashed lines denote 90-percent confidence bands and solid orange lines represent the response to shocks from the baseline model estimated on the (time-varying) European Union sample. 